\title{
Training of literacy-oriented teaching material development in MTs Al Ikhlas Soe, East Nusa Tenggara
}

\author{
Nurdiyah Lestari ${ }^{\mathrm{a}, 1,}{ }^{*}$, St.Muthmainnah Yusuf ${ }^{\mathrm{b}, 1}$, I. Ihwan ${ }^{\mathrm{a}, 2}$, .M. Mahfud ${ }^{\mathrm{a}, 3}$, E. Ernawati ${ }^{\mathrm{a}, 4}$, Nur Jannah ${ }^{\mathrm{a}, 5}$ \\ ${ }^{a}$ Department of Biology Education, Universitas Muhammadiyah Kupang, Kupang-East Nusa Tenggara 85111, Indonesia \\ ${ }^{b}$ Department of Mathematics Education, Universitas Muhammadiyah Kupang, Kupang-East Nusa Tenggara 85111, Indonesia \\ ${ }^{1}$ nurdiyah.72@gmail.com*; ${ }^{2}$ smuthmainnah@yahoo.co.id; ${ }^{3}$ ihwan.fkipbio@yahoo.com; ${ }^{4}$ mahfud.aph@gmail.com; \\ ${ }^{5}$ ewati0792@gmail.com; ${ }^{1}$ nurjanna616@yahoo.co.id \\ * Corresponding author
}

\begin{abstract}
ARTICLE INFO
ABSTRACT

\section{Article history}

Received: 27 May 2020

Revised: 18 July 2020

Accepted: 24 August 2020

Published: 31 August 2020

\section{Keywords}

literacy

teacher professionalism

teaching material

In accordance with the paradigm of $21^{\text {st }}$ century education, teachers are required to facilitate students with the learning process which addresses the improvement of students' higher thinking skill. The community service which was conducted in MTs Al Ikhlas Soe, East Nusa Tenggara was aimed at: 1) culturing as well as developing students' literacy in school; 2) improving students' capacity in literacy; 3 ) managing students' knowledge and higher thinking skill, as considerable as 4) elevating teachers' professionalism so that learning process can be more effective and efficient. The methods used were lecture, discussion, brainstorming, simulation, and assignment. The materials delivered were about the arrangement and development of literacy-oriented teaching materials. The product produced from the training was implemented in learning process on VII graders. This was aimed to observe whether there was an improvement gained after the training given. The participants of this community service were 13 teachers and 34 students of MTs Al Ikhlas Soe. The results showed that teachers' skill in arranging teaching materials has been improved. Furthermore, students' understanding about the concept or their knowledge related to the materials has been upgraded after experiencing the implementation of literacy-oriented learning.
\end{abstract}

Check for updates
Copyright (C) 2020, Lestari et al This is an open access article under the CC-BY-SA license

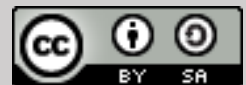

How to cite: Lestari, N., Yusuf, S., Ihwan, I., Mahfud, M., Ernawati, E., \& Jannah, N. (2020). Training of literacy-oriented teaching material development in MTs Al Ikhlas Soe, East Nusa Tenggara. Journal of Community Service and Empowerment, 1(2), 73-79. doi: https://doi.org/10.22219/jcse.v1i2.12312

\section{PENDAHULUAN}

Penguasaan sains dan teknologi merupakan kunci penting keberhasilan bangsa memasuki abad ke-21 (Griffin \& Care, 2015). Keberhasilan ini juga menjadi tolak ukur keberhasilan suatu bangsa dalam memasuki kancah persaingan global. Oleh sebab itu pendidikan hendaknya dirancang agar mampu membentuk peserta didik agar memiliki kemampuan berpikir kritis, logis, kreatif, inovatif, dan berdaya saing global. Lebih lanjut, kemampuan literasi bidang ilmu menjadi kemampuan penting yang harus dikuasai siswa agar mampu bertahan hidup dan berkehidupan pada abad ke-21. Memasuki abad ke21, pembelajaran literasi memiliki tujuan utama untuk memberikan kesempatan kepada siswa untuk mengembangkan dirinya sebagai komunikator (Scott, 2015), serta meningkatkan kemampuan berpikir. Berdasarkan paradigma tersebut, maka pendekatan pembelajaran harus selalu mengedepankan proses pembelajaran.

Pasal 1 ayat (4) Undang-undang Nomor 3 Tahun 2017 tentang Perbukuan menyatakan bahwa: "Literasi adalah kemampuan untuk memaknai informasi secara kritis sehingga setiap orang dapat mengakses ilmu pengetahuan dan teknologi sebagai upaya dalam meningkatkan kualitas hidupnya." Literasi adalah kemampuan individu untuk menggunakan segenap potensi dan skill yang dimiliki dalam hidupnya. Menurut Kemdikbud (2016), paradigma baru abad 21 mengutamakan kolaborasi bukan kompetisi. Dengan demikian kompetensi dalam pembelajaran bukan hanya ditinjau dari aspek kognitif saja, tetapi aspek afektif dan psikomotorik juga perlu dipertimbangkan. 
Fakta di lapangan menunjukkan bahwa literasi siswa dalam proses pendidikan belum mengembangkan kompetensi dan minat siswa terhadap pengetahuan. Proses pembelajaran yang dilakukan oleh guru selama ini belum mengedepankan tujuan meningkatkan kemampuan berpikir siswa sesuai yang diharapkan pada abad 21, serta belum mampu meningkatkan pemahaman konsep siswa terhadap suatu materi sehingga pembelajaran terkesan kurang bermakna. Hasil PISA (Programme for International Student Assessment) 2018, menunjukkan bahwa kemampuan membaca (literasi) peserta didik Indonesia, selain matematika dan sains, berada di peringkat 74 dari 79 negara dengan skor rata-rata 371 (OECD, 2019). Maka, transfer IPTEK perlu dilakukan melalui kegiatan pengabdian bagi guru-guru yaitu berupa kegiatan pelatihan dan pendampingan penyusunan bahan ajar bagi guru yang yang nantinya akan diterapkan dalam proses pembelajaran. Peningkatan literasi siswa juga perlu dilakukan terkait permasalahan tersebut.

MTs Al Ikhlas Soe merupakan salah satu sekolah yang terletak di kabupaten TTS, dan berjarak 109,8 km dari kota Kupang Nusa Tenggara Timur. Berdasarkan wawancara dengan Kepala sekolah dan sebagian guru, terdapat beberapa permasalahan yang ada terkait dengan peningkatan kualitas pembelajaran secara umum dan peningkatan kualitas profesionalisme guru. Adapun permasalahan tersebut diantaranya adalah: 1) sebagian besar guru belum pernah mendapatkan kesempatan untuk mengikuti kegiatan pelatihan atau workshop yang bertujuan untuk meningkatkan profesionalisme dan 2) rendahnya pemahaman guru berkaitan dengan langkah penyusunan atau pengembangan bahan ajar yang inovatif dan kreatif. Permasalahan lain yang juga dijumpai adalah kurangnya kemampuan guru dalam mengimplementasikan model pembelajaran berorientasi literasi. Hal ini mengakibatkan pembelajaran menjadi tidak bermakna dan berpengaruh terhadap pengetahuan atau pemahaman yang dimiliki siswa. Selain itu, pembelajaran di sekolah belum mampu mengajarkan kompetensi abad 21. Hal ini tampak dengan fakta belum diterapkannya budaya literasi di sekolah MTs Al Ikhlas Soe. Konsekwensinya, siswa belum mampu memahami informasi secara analitis, kritis, dan reflektif dalam setiap proses pembelajaran.

Berdasarkan permasalahan yang ada menjadi kewajiban guru untuk meningkatkan literasi siswa melalui penggunaan berbagai model, metode maupun strategi yang dikemas dalam suatu bahan ajar yang digunakan. Menurut Abidin, Mulyati, dan Yunansah (2017), literasi disipliner merupakan literasi yang menekankan penggunaan membaca, logika, penelitian, berbicara dan menulis untuk mempelajari dan membentuk pemahaman yang kompleks atas konten pengetahuan yang berhubungan dengan bidang keilmuan tertentu. Siswa yang belajar melalui pendekatan multiliterasi akan memperoleh pemahaman yang tinggi (lyer dan Luke, 2010). Peningkatan literasi sains siswa dapat dilakukan melalui penyusunan buku ajar yang berorientasi literasi sains siswa dan sesuai dengan pola pembelajarannya. Efektifitas pembelajaran diukur dari basis literasi yang berwujud pemahaman terhadap berbagai jenis teks (D. W. Aisyah, Gipayana, \& Djatmika, 2017; Budiningsih, Rusilowati, \& Marwoto, 2015) maupun media visual (R. Aisyah, Zakiyah, Farida, \& Ramdhani, 2017; Yamadarice, 2011).

Dalam konteks era literasi, guru harus berliterasi efektif yang memiliki karakteristik mampu bekerjasama dengan siswa dan seluruh pihak yang terlibat dengan sekolah, menguasai dan mempraktekkan berbagai strategi evaluasi kemampuan siswa (Griffin \& Care, 2015), serta menguasai dan menggunakan media maupun bahan ajar literasi (Anastasiades \& Vitalaki, 2011; Griffin \& Care, 2015). Pembelajaran literasi pada jenjang sekolah menengah bertujuan membawa siswa melompat jauh ke depan. Terdapat hubungan antar keterampilan berpikir kritis dan literasi sains (Abidin et al., 2017; Rahayuni, 2016) maupun performa akademik (Tanujaya, Mumu, \& Margono, 2017). Fungsi bahan ajar bagi guru adalah untuk mengarahkan semua aktivitasnya dalam proses pembelajaran sekaligus merupakan substansi kompetensi yang seharusnya diajarkan kepada siswa. Tujuan penyusunan bahan ajar adalah agar siswa dapat belajar secara mandiri, dan dapat menemukan arahan yang terstruktur untuk memahami materi yang diberikan. Dengan demikian, bahan ajar yang dibuat oleh pendidik dalam pembelajaran akan lebih menarik dan mengesankan bagi siswa, serta lebih efektif (Lestari, 2013; Prastowo, 2011).

Hanya saja, kompetensi dalam membuat bahan ajar ini belum dimiliki oleh para guru di MTs Al Ikhlas Soe. Kegiatan pengabdian yang dilakukan dapat memberikan kontribusi pada 1) peningkatan kompetensi guru untuk menyusun perangkat maupun bahan ajar yang sesuai capaian pembelajaran dan indokator yang diharapkan; 2) peningkatan kompetensi pemahaman guru dan siswa terkait dengan literasi. Jika kedua hal tersebut sudah tercapai, maka diharapkan terjadi peningkatan kualitas pendidikan di sekolah mitra yaitu MTs Al Ikhlas Soe Kab Timur Tengah Selatan khususnya, dan di Nusa Tenggara Timur pada umumnya.

Adapun tujuan dari kegiatan yang dilaksanakan adalah 1) menumbuhkembangkan budaya literasi siswa di sekolah, 2) meningkatkan kapasitas siswa agar lebih berliterasi, 3) menjadikan sekolah sebagai taman belajar yang menyenangkan dan ramah anak agar warga sekolah mampu mengelola pengetahuan dan kemampuan berpikir tingkat tinggi, dan 4) meningkatkan profesionalisme guru agar proses pembelajaran menjadi ebih efektif dan efisien.

\section{METODE}

Pelaksanaan kegiatan pengabdian dilaksanakan di MTs Al Ikhlas Soe melibatkan guru mitra berjumlah 13 orang. Implementasi bahan ajar sebagai langkah penerapan basis model pembelajaran dilakukan pada siswa kelas VII yang berjumlah 34 orang. Kegiatan ini dilaksanakan pada bulan April hingga Mei tahun 2020 sebanyak 4 kali pertemuan yang meliputi penyampaian materi dalam bentuk pelatihan dan pendampingan serta implementasi bahan ajar. Pada akhir 
kegiatan pengabdian dilakukan evaluasi keberhasilan program yang dilaksanakan. Secara garis besar, terdapat tiga tahap pelaksanaan kegiatan pengabdian sebagai berikut.

\section{Persiapan}

Pada tahap persiapan terdapat beberapa kegiatan yang dilakukan diantaranya adalah melakukan rapat koordinasi bersama tim pelaksana kegiatan pengabdian, serta menentukan jadwal kegiatan maupun agenda kegiatan. Selanjutnya adalah mempersiapkan instrumen, alat, dan bahan atau materi terkait kegiatan pengabdian.

\section{Pelaksanaan kegiatan (pelatihan dan pendampingan bahan ajar)}

Langkah yang dilakukan pada tahap pelaksanaan adalah melaksanakan kegiatan pelatihan sesuai jadwal yang telah disusun dan direncanakan. Materi penyusunan dan pengembangan bahan ajar diberikan dengan menyampaikan teori berupa materi tentang kompetensi dasar, tujuan, indikator, model atau pendekatan yang digunakan, serta format bahan ajar yang disusun. Adapun metode yang dipilih adalah ceramah, diskusi, brainstorming, dan simulasi tentang topik permasalahan. Selanjutnya peserta pelatihan, dalam hal ini guru-guru di sekolah mitra, diberi penugasan untuk menyusun bahan ajar berorientasi literasi dan dilakukan pendampingan oleh tim pelaksana kegiatan pengabdian. Target peningkatan literasi bukan hanya guru-guru di MTs Al Ikhlas, tetapi juga siswa-siswanya. Siswa diberikan materi dengan bahan ajar berorientasi literasi melalui demonstrasi maupun simulasi.

\section{Observasi dan evaluasi}

Tahap ini bertujuan mengetahui tingkat pemahaman guru dan siswa setelah diberikan materi pelatihan, serta untuk mengetahui tingkat keberhasilan kegiatan pengabdian yang telah dilakukan. Untuk mengetahui indikator keberhasilan kegiatan, selanjutnya dilakukan implementasi dalam proses pembelajaran di kelas VII MTs Al Ikhlas Soe menggunakan bahan ajar yang telah disusun. Adapun tujuan dari implementasi dalam proses pembelajaran adalah untuk mencobakan model pembelajaran literasi dalam pembelajaran. Implementasi dalam proses pembelajaran dilaksanakan sebagai hasil refleksi dari kegiatan pengabdian yang telah dilaksanakan. Fokus kegiatan literasi sekolah yang diterapkan dalam kegiatan mengacu pada (Kemdikbud, 2016) berupa tahapan: 1) pembiasaan; 2) pengembangan; dan 3) pembelajaran. Indikator keberhasilan dari implementasi program siswa adalah diukur dengan memberikan angket respon kepada siswa sesuai materi yang telah disampaikan yaitu tentang literasi dalam pembelajaran dengan menggunakan skala Likert (Sugiono, 2015). Selain itu, siswa juga diberikan soal pretest maupun posttest terkait literasi siswa. Hasil dari pretes dan postes kemudian dibandingkan. Sedangkan evaluasi terhadap guru adalah dengan memberikan kuesioner serta dilakukan penilaian hasil pengembangan bahan ajar setelah selesai pendampingan oleh tim pelaksana.

\section{HASIL DAN PEMBAHASAN}

Kegiatan pengabdian diawali dengan langkah persiapan pelaksanaan kegiatan dan koordinasi dengan sekolah mitra yang digunakan untuk pelaksanaan kegiatan pengabdian. Pada dasarnya kegiatan dilaksanakan dalam rangka menyelesaikan permasalahan yang ada di sekolah mitra yaitu MTs Al Ikhlas Soe. Adapun hasil dari pelaksanaan kegiatan secara menyeluruh adalah sebagai berikut.

\section{Persiapan kegiatan}

Setelah dilakukan rapat koordinasi oleh tim pelaksana kegiatan pengabdian, langkah yang dilakukan adalah melakukan koordinasi dengan sekolah mitra terkait rencana tanggal pelaksanaan dan agenda kegiatan yang akan dilaksanakan pada kegiatan pengabdian (Gambar 1). Kegiatan dilakukan sebagai solusi dari permasalahan yang dijumpai di sekolah mitra yaitu bahwa selama ini proses pembelajaran belum menerapkan bahan ajar yang inovatif dan kreatif sesuai model pembelajaran tertentu atau dapat dikatakan masih bersifat konvensional. Selain itu, budaya literasi belum diterapkan secara maksimal oleh warga sekolah, serta pembelajaran belum dilaksanakan untuk melatih kemampuan tingkat tinggi siswa. Solusi dari permasalahan yang ada dengan melakukan pelatihan dan pendampingan tentang penyusunan bahan ajar berorientasi literasi. Pada langkah persiapan disusun materi dalam Powerpoint tentang langkah penyusunan bahan ajar, serta menyiapkan contoh-contoh bahan ajar sesuai model pembelajaran yang akan dilaksanakan. Selain materi, tim pelaksana juga menyiapkan angket, soal-soal pretest, maupun alat dan bahan untuk implementasi proses pembelajaran berorientasi literasi. 


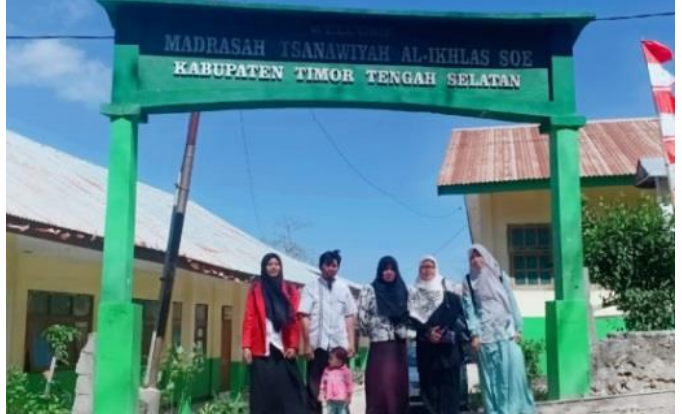

Gambar 1. Kunjungan awal ke sekolah

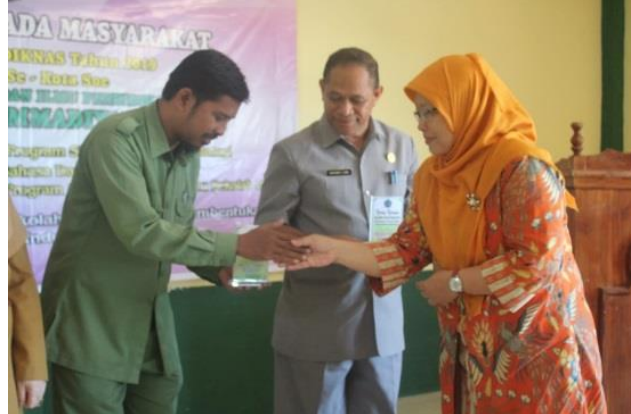

Gambar 2. Acara pembukaan kegiatan pengabdian

\section{Pelaksanaan Kegiatan (Pelatihan dan pendampingan bahan ajar)}

Kegiatan pelatihan dan pendampingan diikuti oleh seluruh guru yang ada di MTs Al Ikhlas Soe yang berjumlah 13 orang. Kegiatan awal pelatihan dilaksanakan pada tanggal 16 April 2019 (Gambar 2). Pada tahapan pelaksanaan kegiatan narasumber yaitu dosen FKIP Universitas Muhammadiyah Kupang yaitu Nurdiyah Lestari, S.Pd., M.Pd menyampaikan materi tentang penyusunan bahan ajar. Materi yang disampaikan adalah berupa langkah-langkah pokok pembuatan bahan ajar mulai dari analisis kebutuhan bahan ajar, analisis sumber belajar, hingga struktur bahan ajar sesuai tujuan penyusunannya. Terkait materi tentang literasi, diharapkan guru mampu merancang bahan ajar yang sesuai dengan tujuan paradigma pendidikan abad 21. Pembelajaran diawali dengan memberikan suatu permasalahan yang harus diselesaikan siswa melalui langkah diskusi kelompok dan siswa diharapkan mampu mempresentasikan hasil diskusinya. Narasumber lain yaitu Ihwan, S.Pd., M.Si selaku dosen pendidikan Biologi FKIP UMK memberikan materi tentang pemahaman literasi kepada siswa kelas VII di MTs Al Ikhlas Soe melalui demonstrasi atau praktek materi Biologi secara langsung.

Materi simulasi dan demonstrasi menunjukkan bahwa pembelajaran yang bertujuan untuk meningkatkan kemampuan berpikir tingkat tinggi siswa adalah dengan diawali adanya orientasi suatu masalah dalam setiap langkah awal pembelajaran. Kekuatan pemecahan masalah yang dimilki siswa memiliki manfaat atau tujuan yaitu menyiapkan siswa dalam menghadapi tantangan dalam hidup masa depan. Implementasi dalam pembelajaran bertujuan untuk mengetahui respon siswa setelah diberikan bahan ajar berorientasi literasi, serta untuk mengetahui peningkatan literasi siswa. Kegiatan diawali dengan memberikan soal pretest kepada siswa berupa soal pilihan ganda menggunakan indikator literasi. Mayer (2014), mendefinisikan pemecahan masalah sebagai proses kognitif yang diarahkan untuk mengubah situasi tertentu ke dalam situasi tujuan dengan berbasis pada kejelasan metode. Pemecahan masalah adalah upaya aktif untuk mencapai tujuan yang tidak mudah dicapai. Kegiatan pengabdian melalui pembelajaran berorientasi literasi di MTs Al Ikhlas Soe, terkait dengan pembelajaran berbasis masalah, diharapkan akan lebih bermakna bagi siswa. Hal ini karena siswa mengalami pembelajaran secara nyata sesuai karakteristik pembelajaran. Adanya pemahaman tentang proses pengembangan budaya literasi akan membentuk kemudahan kepada pihak sekolah dalam melakukan proses pengembangan budaya literasi sehingga berdampak pada pencapaian tujuan secara efektif dan efisien, dan akan berdampak pada tingkat keberhasilannya di masyarakat (Marmoah, Hartono, \& Sadiman, 2019; Saadati \& Sadli, 2019).

Kegiatan pelatihan tidak hanya dilakukan dengan penyampaian materi saja, akan tetapi guru juga diberikan penugasan untuk menyusun bahan ajar sesuai dengan bidang keahlian atau mata pelajaran yang diajarkan. Pendampingan dilaksanakan secara bertahap sesuai dengan kesepakatan antara tim pelaksana dengan peserta yang selanjutnya dihasilkan bahan ajar untuk diimplementasikan dalam proses pembelajaran.

Hasil kegiatan pelatihan dan pendampingan yang telah dilaksanakan menunjukkan bahwa kegiatan ini memberikan dampak positif dan direspon baik oleh para guru peserta pelatihan dan pendampingan maupun oleh siswa. Berdasarkan wawancara dengan guru, kegiatan pelatihan yang berkaitan dengan peningkatan profesionalisme guru jarang dilakukan. Pada saat kegiatan, peserta terlihat sangat antusias untuk mengikuti kegiatan yang telah disampaikan oleh para pemateri (Tim Pengabdian FKIP UMK).

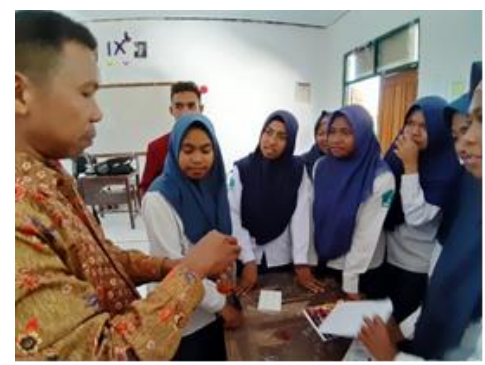

Gambar 3. Materi pemecahan masalah (literasi)

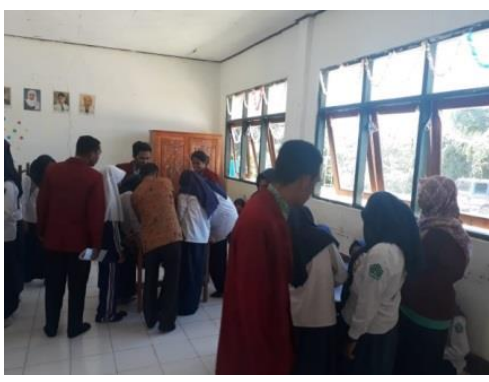

Gambar 4. Simulasi materi pada siswa kelas VII 


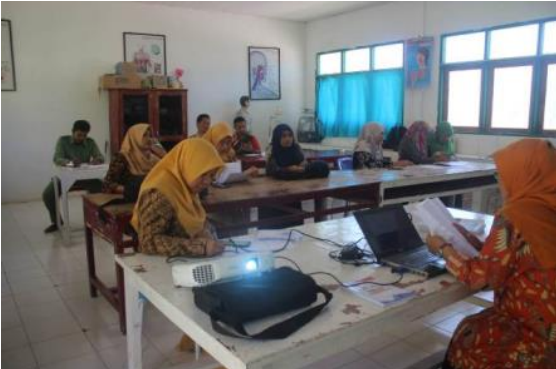

Gambar 5. Guru diberikan kuesioner

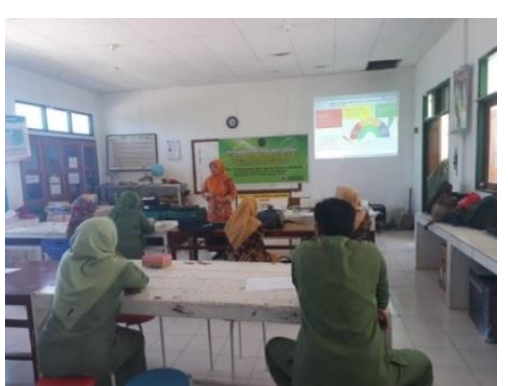

Gambar 6. Peserta antusias mendengarkan materi

\section{Observasi dan Evaluasi}

Tahap akhir kegiatan pengabdian adalah observasi dan evaluasi. Kegiatan observasi dilaksanakan untuk menilai produk bahan ajar yang dikembangkan sebagai hasil penugasan kepada para guru. Kegiatan dilaksanakan pada pertemuan ketiga dari jadwal yang sudah ditetapkan. Setelah melalui konsultasi dan pendampingan, tim pelaksana pengabdian melihat adanya peningkatan pemahaman guru tentang penyusunan bahan ajar disertai dengan model yang diterapkan. Evaluasi dilakukan dengan pemberian kuesioner kepada guru terkait materi yang disampaikan dan untuk mengetahui penguasaan guru terhadap perangkat maupun bahan ajar yang berkualitas. Indikator ketercapaian kegiatan pengabdian adalah seperti tertera dalam Tabel 1.

Tabel 1. Indikator ketercapaian kegiatan pengabdian

\begin{tabular}{clc}
\hline No. & \multicolumn{1}{c}{ Indikator } & Persentase (\%) \\
\hline 1 & Guru memahami langkah-langkah penyusunan dan pengembangan bahan ajar & 90 \\
2 & $\begin{array}{l}\text { Guru mampu menganalisis Standar Isi, KI maupun KD sesuai kebutuhan dalam penyusunan bahan ajar } \\
\text { setelah dilakukan pelatihan dan pendampingan }\end{array}$ & 95 \\
3 & Guru mampu mengembangkan perangkat pembelajaran yaitu silabus maupun RPP terkait bahan ajar & 95 \\
& yang akan disusun & 85 \\
4 & Guru mampu menentukann indikator keberhasilan dari setiap KD yang dipilih & 95 \\
5 & Dalam melakukan kegiatan pelatihan dan pendampingan guru terlihat sangat antusias & 85 \\
6 & Guru memahami dan mampu mengembangkan bahan cetak & 90 \\
7 & Adanya manfaat berupa peningkatan profesionalisme yang dirasakan oleh guru & 90 \\
8 & Adanya peningkatan paedagogik setelah dilakukan pelatihan dan pendampingan & \\
\hline
\end{tabular}

Berdasarkan Tabel 1, dapat dilihat indikator ketercapaian Kegiatan pengabdian yang dilaksanakan di MTs Al Ikhlas Soe, yatu pada peningkatan profesionalisme dan peningkatan paedagogik guru. Indikator tersebut menunjukkan bahwa tujuan dilakukannya kegiatan pengabdian tersebut adalah agar sekolah memiliki suatu program literasi melalui model atau metode pembelajaran literasi dalam pembelajaran di seluruh mata pelajaran dan guru merupakan modal dasar pertama yang harus ada untuk mewujudkannya. Analisis masalah yang ada menunjukkan pada awalnya guru belum mampu menyusun atau mengembangkan bahan ajar, tetapi setelah dilakukan pendampingan, guru dapat mengembangkannya sesuai bidang studi masing-masing. Adanya pembudayaan gerakan literasi di sekolah memiliki dampak positif terhadap kemampuan literasi siswa jika diterapkan pada setiap mata pelajaran. Pembelajaran literasi sains dapat meningkatkan hasil belajar siswa jika implementasinya terintegrasi dalam kurikulum (Budiningsih et al., 2015).

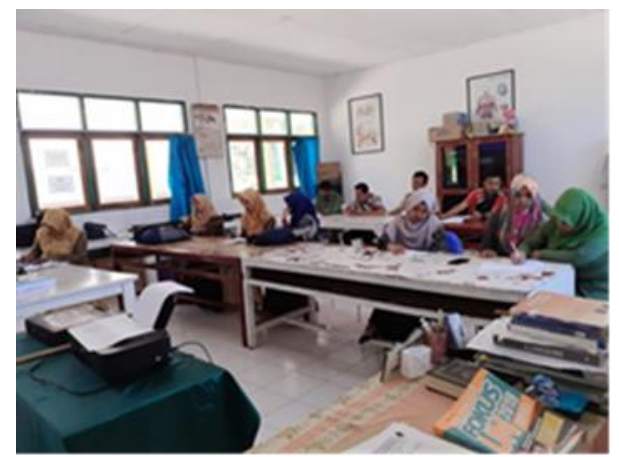

Gambar 7. Pendampingan penyusunan bahan ajar

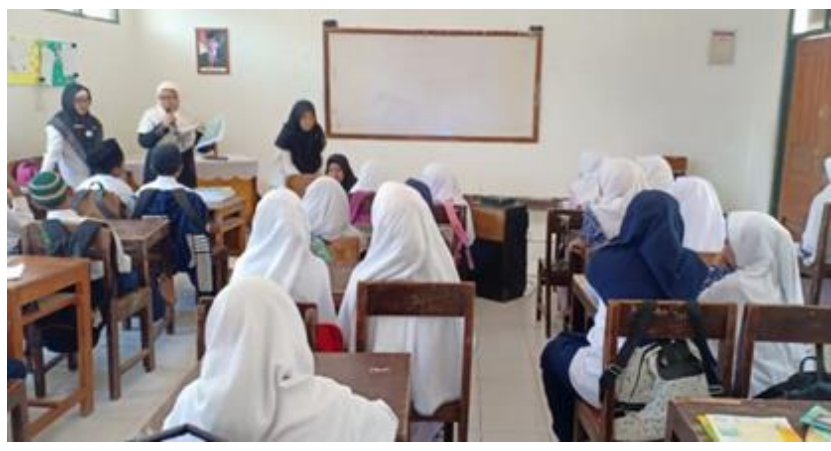

Gambar 8. Kegiatan pendampingan pembelajaran

Evaluasi juga dilakukan terhadap siswa melalui angket yang diberikan dengan indikator literasi. Selain itu siswa diberikan soal pretest dan posttest setelah diberikan materi dengan metode ceramah dan simulasi. Hasil posttest yang diperoleh 
dapat digunakan sebagai langkah untuk mengetahui adanya peningkatan pemahaman siswa terkait materi yang diberikan oleh tim pelaksana. Adapun perbandingan nilai pretest dan posttest seperti terlihat pada Gambar 1.

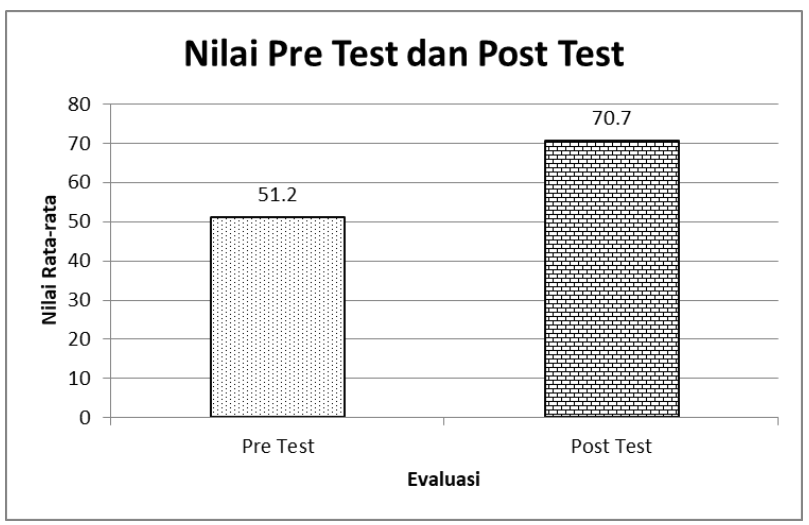

Gambar 9. Perbandingan hasil pretest dan posttest

Berdasarkan Gambar 9 dapat dilihat adanya peningkatan pemahaman siswa yang ditunjukkan oleh rata-rata nilai pretest sebesar $51,2 \%$ dan rata-rata nilai posttest sebesar $70,7 \%$. Hal ini menunjukkan bahwa tujuan pembelajaran untuk meningkatkan kemampuan berpikir tingkat tinggi berbasis literasi bagi siswa di MTs Al Ikhlas dapat dikatakan efektif. Menurut Berger, Woodfin, Plaut, dan Dobbertin, (2014), pembelajaran literasi ditujukan untuk membentuk siswa yang memiliki karakteristik: 1) menunjukkan kemandirian belajar; 2) memiliki pengetahuan keilmuan yang kuat; 3) responsif terhadap audiens, tugas, tujuan, dan disiplin; 3) memiliki pemahaman dan daya kritik yang baik; 5) menghargai peristiwa; 6) mahir dan strategis dalam menggunakan teknologi; dan 7) memahami keberagaman perspektif dan budaya. Rendahnya literasi sains siswa di Indonesia dipengaruhi oleh beberapa hal antara lain adalah kurikulum dan sistem pendidikan, metode atau model pembelajaran, sarana prasarana, sumber belajar serta bahan ajar. Pembelajaran dengan model berbasis masalah berpengaruh tinggi terhadap peningkatan literasi sains dalam pembelajaran IPA (Eviani, Utami, \& Sabri, 2014; Kurnia, Zulherman, \& Fathurohman, 2014).

Melalui kegiatan pelatihan dan pendampingan diharapkan guru mampu merancang berbagai bahan ajar yang sesuai dengan kompetensi yang akan dicapai dalam pembelajaran. Bahan ajar berorientasi literasi yang dirancang oleh guru sesuai dengan karakteristik literasi, dan harus memberikan petunjuk bagi siswa untuk mempelajari suatu materi berdasarkan suatu permasalahan.

\section{KESIMPULAN}

Hasil dari kegiatan pengabdian adalah adanya peningkatan profesionalisme dan paedagogik guru terkait penyusunan dan pengembangan bahan ajar berbasis literasi. Kegiatan pengabdian yang dilaksanakan mendapatkan hasil bahwa guru dan siswa merasa senang dan antusias mengikuti kegiatan dan sangat berharap agar kegiatan serupa sering dilaksanakan dengan materi yang lain karena kegiatan pelatihan dengan tujuan peningkatan profesionalisme guru atau peningkatan kualitas pendidikan sangat jarang dilakukan. Setelah dilakukan kegiatan simulasi dengan materi yang terkait literasi, siswa merasa lebih mudah dalam memahami konsep atau pengetahuan yang diberikan oleh guru dalam pembelajaran sehingga pembelajaran menjadi lebih bermakna. Terdapat peningkatan pemahaman siswa tentang pembelajaran berorientasi literasi, ditunjukkan dengan rata-rata nilai pretest dan posttest yang mengalami peningkatan nilai rata-rata.

\section{DAFTAR PUSTAKA}

Abidin, Y., Mulyati, T., \& Yunansah, H. (2017). Pembelajaran literasi. Jakarta: Bumi Aksara.

Aisyah, D. W., Gipayana, M., \& Djatmika, E. T. (2017). Pengembangan bahan ajar berbasis literasi bercirikan Quantum Teaching untuk mengoptimalkan embelajaran efektif dan produktif. Jurnal Pendidikan: Teori, Penelitian, Dan Pengembangan, 2(5), 667-475. Retrieved from http://journal.um.ac.id/index.php/jptpp/article/view/10144/4829

Aisyah, R., Zakiyah, I. A., Farida, I., \& Ramdhani, M. A. (2017). Learning crude oil by using scientific literacy comics. In Journal of Physics: Conference Series (Vol. 895, pp. 1-7). IOP Publishing. http://doi.org/10.1088/17426596/895/1/012011

Anastasiades, P. S., \& Vitalaki, E. (2011). Promoting internet safety in Greek primary schools: the teacher's role. Educational Technology and Society, 14(2), 71-80.

Berger, R., Woodfin, L., Plaut, S. N., \& Dobbertin, C. B. (2014). Transformational literacy: Making the common core shift with work that matters. San Fransisco: John Wiley dan Sons, Inc. Retrieved from https://www.americanreading.com/el-education/overlay/9781118962237

Budiningsih, T. Y., Rusilowati, A., \& Marwoto, P. (2015). Pengembangan buku ajar IPA terpadu berorientasi literasi sains 
materi energi dan suhu. Journal of Innovative Science Education, 4(2), 34-40. Retrieved from https://journal.unnes.ac.id/sju/index.php/jise/article/view/9902/6349

Eviani, E., Utami, S., \& Sabri, T. (2014). Pengaruh model pembelajaran berbasis masalah terhadap kemampuan literasi sains IPA kelas V SD. Jurnal Pendidikan Dan Pembelajaran Khatulistiwa, 3(7), 1-13. Retrieved from http://jurnal.untan.ac.id/index.php/jpdpb/article/view/5862/6721

Griffin, P., \& Care, E. (2015). Assessment and teaching of 21st century skills. London: Springer Dordrecht Heidelberg. http://doi.org/10.1007/978-94-017-9395-7

Kemdikbud. (2016). Panduan gerakan literasi di sekolah menengah pertama. Jakarta: Direktorat Pembinaan Sekolah Menengah Pertama.

Kurnia, F., Zulherman, \& Fathurohman, A. (2014). Analisis bahan ajar Fisika SMA kelas XI di Kecamatan Indralaya Utara berdasarkan kategori literasi sains. Jurnal Inovasi Dan Pembelajaran Fisika, 1(1), 43-47. Retrieved from https://ejournal.unsri.ac.id/index.php/jipf/article/view/1263/419

Lestari, I. (2013). Pengembangan bahan ajar berbasis kompetensi. Padang: Akademia Permata.

Marmoah, S., Hartono, H., \& Sadiman, S. (2019). Implementation of school-based management through a culture of literacy in elementary schools. Dwija Cendekia: Jurnal Riset Pedagogik, 3(2), 238-247. Retrieved from https://jurnal.uns.ac.id/jdc/article/view/35349/25559

Mayer, D. . (2014). Eksploring psychologi ninth edition. New York: Worth Publisher. Retrieved from https://www.amazon.ca/Psychology-David-G-Myers/dp/1429261781

OECD. (2019). PISA 2018 insight and interpretations. OECD. Retrieved from https://www.oecd.org/pisa/PISA 2018 Insights and Interpretations FINAL PDF.pdf

Prastowo, P. (2011). Panduan kreatif membuat bahan ajar inovatif. Yogyakarta: DIVA Press.

Rahayuni, G. (2016). Hubungan keterampilan berpikir kritis dan literasi sains pada pembelajaran IPA terpadu dengan model PBM dan STM. Jurnal Penelitian Dan Pembelajaran IPA, 2(2), 131-146. Retrieved from http://jurnal.untirta.ac.id/index.php/JPPI/article/view/926/811

Saadati, B. A., \& Sadli, M. (2019). Analisis pengembangan budaya literasi dalam meningkatkan minat membaca siswa sekolah dasar. Terampil, 6(2), 151-164. http://doi.org/10.24042/terampil.v6i2.4829

Scott, C. L. (2015). The futures of learning 2: What kind of learning for the 21st Century? (No. 14). Ireland. Retrieved from http://unesdoc.unesco.org/images/0024/002429/242996E.pdf

Sugiono, P. M. (2015). Metode penelitian dan pengembangan. Res. Dev. D, 39-41.

Tanujaya, B., Mumu, J., \& Margono, G. (2017). The relationship between higher order thinking skills and academic performance of student in Mathematics instruction. International Education Studies, 10(11), 78. http://doi.org/10.5539/ies.v10n11p78

Yamada-rice, D. (2011). New media, evolving multimodal literacy literacy practices and the potential impact on increased use of the visual mode in the urban environment on young children's learning. Literacy, 45(1), 32-43. http://doi.org/10.1111/j.1741-4369.2011.00578.x 